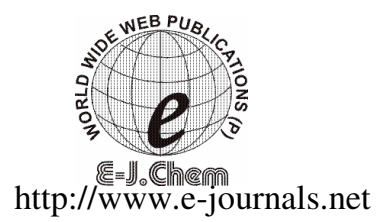

\title{
Kinetic Approach for the Adsorption of Organophosphorous Pesticides from Aqueous Solution Using "Waste" Jute Fiber Carbon
}

\author{
S. SENTHILKUMAAR ${ }^{*}$, S.K. KRISHNA ${ }^{\#}$, P. KALAAMANI ${ }^{\S}$ \\ C. V. SUBBURAMAAN, N. GANAPATHY SUBRAMANIAM ${ }^{\mathbb{I l}}$ and TW KANG ${ }^{\mathbb{I}}$ \\ *Department of Chemistry, PSG College of Technology, Coimbatore, India \\ "Department of Chemistry, MPNMJ Engineering College, Erode, India \\ ${ }^{\S}$ Department of Chemistry, N.G.M.College, Pollachi, India \\ School of Environmental Sciences, Bharathiar University, Coimbatore, India \\ ${ }^{\text {II }}$ Quantum Functional Semiconductor Research Centre (QSRC) \\ Dongguk University-Seoul, Korea Republic \\ sskumaarchem@rediffmail.com
}

\section{Received 25 February 2010; Accepted 20 April 2010}

\begin{abstract}
Chemically activated "Waste" Jute Fiber carbon has been effectively used for the removal of five organophosphorous pesticides (malathion, monocrotophos, methylparathion, phosphamidon and dimethoate) from aqueous solutions. The prepared activated jute fiber carbon was characterized by using Elemental analyzer and proximate analysis methods. The adsorption equilibrium was examined at $28{ }^{\circ} \mathrm{C}$. Three different kinetic models, the pseudo first order, pseudo second order and Elovich kinetic models were selected to analyses the adsorption process. To compare the fitness of pseudo first order and pseudo second order, sum of the squares of the errors and correlation coefficient, $\mathrm{r}^{2}$ values were calculated. The Elovich model was used to confirm the chemisorptions.
\end{abstract}

Keywords: Pesticides, Waste jute fiber carbon, Characterization, Adsorption, Kinetics.

\section{Introduction}

A pesticide gives potential hazards to animals, humans and aquatic life ${ }^{1 .}$ They also cause deleterious effect on soil fertility and crop productivity. They enter into cyclic environment process such as absorption by soil, leaching by water ${ }^{2}$. Pesticides are very dangerous and harmful because of their toxic and carcinogenic in nature ${ }^{3}$. Organophosphorous pesticides (OPPs) are frequently used to control the pest in the agricultural field. Common members of the family are methylparathion, malathion, dimethoate, phosphamidon, phorate, fenitrothion, monocrotophos etc. Therefore, the removal of OPPs from water is one of the major environmental concerns. Some treatment methods such as biodegraation ${ }^{4}$, extraction ${ }^{5}$, solidphase extraction $^{6}$, photocatalysis $^{7}$, photo-fenton $^{8}$, flocculation $^{9}$, ion-exchance ${ }^{10}$, chlorination and ozonisation ${ }^{11}$ and adsorption have been used to remove toxic materials from aqueous solutions. 
In the recent years, adsorption has become one of the most important processes for the removal of organic pollutant from water ${ }^{12-18}$. Currently, the use of new low cost agricultural by product materials such as tea leaves ${ }^{19}$, biomass ${ }^{13}$, chickpea husk $^{20}$, olive stones ${ }^{21}$, cotton stalk $^{22}$, rice bran, rice husk, bagasse fly $\operatorname{ash}^{23,24}$, date stone ${ }^{25,26}$, biowaste ${ }^{27}$, coconut tree male flower $^{28,29}$ and Jute fiber ${ }^{28,30}$ is being considered as adsorbent for the removal of toxic chemicals from aqueous solutions. In this study, we prepared sulphuric acid activated "Waste" jute fiber carbon (JFC) was used as a low-cost material for the removal of five OPPs from aqueous solution. Recently, our research group successfully used "waste" jute fiber carbon (JFC) as adsorbent for the dye removal ${ }^{30}$.

\section{Experimental}

Technical grade malathion (CAS No: 121-75-5), methyl parathion (CAS No: 298-00-0), monocrotophos (CAS No: 6923-22- 4), phosphamidon (CAS No: 13171-21-6) and dimethoate (CAS No: 60-51-5) were used as an adsorbate.

\section{Adsorbent}

Sun dried "waste" Jute Fiber (JF) was carbonized using sulphuric acid (SA) in the weight ratio 4:3 (JF:SA) and kept in hot air oven, maintained at $160{ }^{\circ} \mathrm{C}$ for a period of $12 \mathrm{~h}$. The carbon was then dried for $4 \mathrm{~h}$ at $100{ }^{\circ} \mathrm{C}$. The resulting carbons were washed with distilled water until a constant $\mathrm{pH}$ of the slurry. The dried materials were used as adsorbent for the removal of OPPs.

\section{Elemental and proximate analysis}

Carbon / hydrogen / oxygen / nitrogen / sulfur (C/H/O/N/S) contents of our carbon were analyzed by using elemental analyzer (model CHNO-RAPID, Heraeus Co., Germany). For each analysis, the standard sample was first analyzed for checking the experimental error. All measurements were carried out in duplicate. The proximate analysis was made according to ASTM 3172-3175 standards and the results are given in Table 1.

Table 1. Elemental and proximate analysis of JFC

\section{Batch studies}

\begin{tabular}{cc}
\hline Element & Composition, Wt. \% \\
\hline Carbon & 52.66 \\
Hydrogen & 3.22 \\
Nitrogen & 0.14 \\
Oxygen & 43.03 \\
\hline Contents & Composition, \% \\
\hline Moisture & 12.22 \\
Ash & 2.69 \\
Volatile Matter & 61.28 \\
Fixed Carbon & 23.81 \\
Sulfur & 0.98 \\
\hline
\end{tabular}

In equilibrium experiments, a fixed amount of "Waste" Jute Fiber Carbon (JFC) $(0.5 \mathrm{~g} / \mathrm{L})$ and fifty milliliters of different initial pesticides concentrations (10, 20, 30 and $40 \mathrm{mg} / \mathrm{L}$ ) were taken in a $100 \mathrm{~mL}$ conical flasks. The flasks were agitated at room temperature $\left(28^{\circ} \mathrm{C}\right)$ at $120 \mathrm{rpm}$ for a pre-determined time intervals using thermostatic rotary orbital shaker with an initial $\mathrm{pH}$ 6.57. At time $\mathrm{t}=0$ and equilibrium, the concentration of pesticides were measured using Shimadzu UV-Vis spectrophotometer (Shimadzu Model: UV 1601). 


\section{Adsorption kinetics}

Pseudo first order equation is generally expressed as follows ${ }^{31}$,

$$
d q_{t} / d_{t}=k_{1}\left(q_{e}-q_{t}\right)
$$

Where, $\mathrm{k}_{1}$ is the pseudo first order rate constant. After integration by applying conditions, $\mathrm{q}_{\mathrm{t}}=0$ at $\mathrm{t}=0$ and $\mathrm{q}_{\mathrm{t}}=\mathrm{q}_{\mathrm{t}}$ at $\mathrm{t}=\mathrm{t}$, then equation (1) becomes

$$
\log \left(q_{e}-q_{t}\right)=\log q_{e}-\left(k_{1} / 2.303\right) \mathrm{t}
$$

Where, $\mathrm{q}_{\mathrm{e}}$ is the amount adsorbed at equilibrium of pseudo second order equation. If the rate of adsorption is a second order mechanism, the pseudo second order kinetic rate equation (3) is expressed as ${ }^{32}$,

$$
\frac{d q_{t}}{d_{t}}=k_{2}\left(q_{e-} q_{t}\right)^{2}
$$

Where, $\mathrm{k}_{2}$ is the pseudo second order rate constant. On integrating the equation (3)

$$
t / q_{t}=\left(1 / k_{2} q_{e}^{2}\right)+\left(1 / q_{e}\right) t
$$

\section{Elovich model}

The most interesting model to describe the activated carbon adsorption ${ }^{33}$ is Elovich equation (5),

$$
\frac{d q_{t}}{d_{t}}=a \exp \left(-b q_{t}\right)
$$

Where, ' $a$ ' and ' $b$ ' are constants. The constant ' $a$ ' is considered as the initial adsorption rate $(\mathrm{mg} / \mathrm{g} \mathrm{min})$ and ' $b$ ' is related to the extent of surface coverage and activation energy for adsorptions $(\mathrm{g} / \mathrm{mg}) .\left(\mathrm{dq}_{\mathrm{t}} / \mathrm{dt}\right) \rightarrow \mathrm{a}$ as $\mathrm{q}_{\mathrm{t}} \rightarrow 0$ and given that $\mathrm{q}_{\mathrm{t}}=0$ at $\mathrm{t}=0$, the integrated form of equation (5) becomes,

$$
q_{t}=(1 / b) \ln \left(t+t_{o}\right)-(1 / b) \ln t_{o}
$$

Where, $\mathrm{t}_{\mathrm{o}}=(1 / \mathrm{ab})$. If $\mathrm{t}>\mathrm{t}_{\mathrm{o}}$, equation 6 is simplified as,

$$
q=1 / b \ln a b+1 / b \ln t
$$

Where, ' $a$ ' is the initial adsorption rate $(\mathrm{mg} / \mathrm{g})$, and the parameter ' $\mathrm{b}$ ' is related to the extent of surface coverage. Sum of the squares of the errors, SSE are calculated using the expression ${ }^{34}$

$$
S S E=\sqrt{\sum\left(q_{e} \exp -q_{e} c a l\right)^{2} / N}
$$

Where, $\mathrm{N}$ is the number of data points.

\section{Results and Discussion}

\section{Effect of contact time and initial malathion concentration on adsorption}

Adsorption of pesticides onto waste JFC at different concentrations (10, 20, 30 and $40 \mathrm{mg} / \mathrm{L})$ with fixed adsorbent dose $(0.025 \mathrm{~g} / 50 \mathrm{~mL})$ was carried out at room temperature $\left(28^{\circ} \mathrm{C}\right)$. The effects of pesticide initial concentration with contact time are shown in Figures 1-5, respectively for malathion, monocrotophos, methylparathion, phosphamidon and dimethoate. It shows that, the percent adsorption decrease with increase in the initial pesticide concentration. But the actual amount of pesticides adsorbed per unit mass of carbon increases with increase in pesticides concentration. The curves in the Figures 1-5 are smooth and continuous, suggesting the possible monolayer coverage of pesticides on JFC surface. Similar results were reported by various researchers for the adsorption of pesticides onto different adsorbents $\mathrm{s}^{23,30,35}$. 

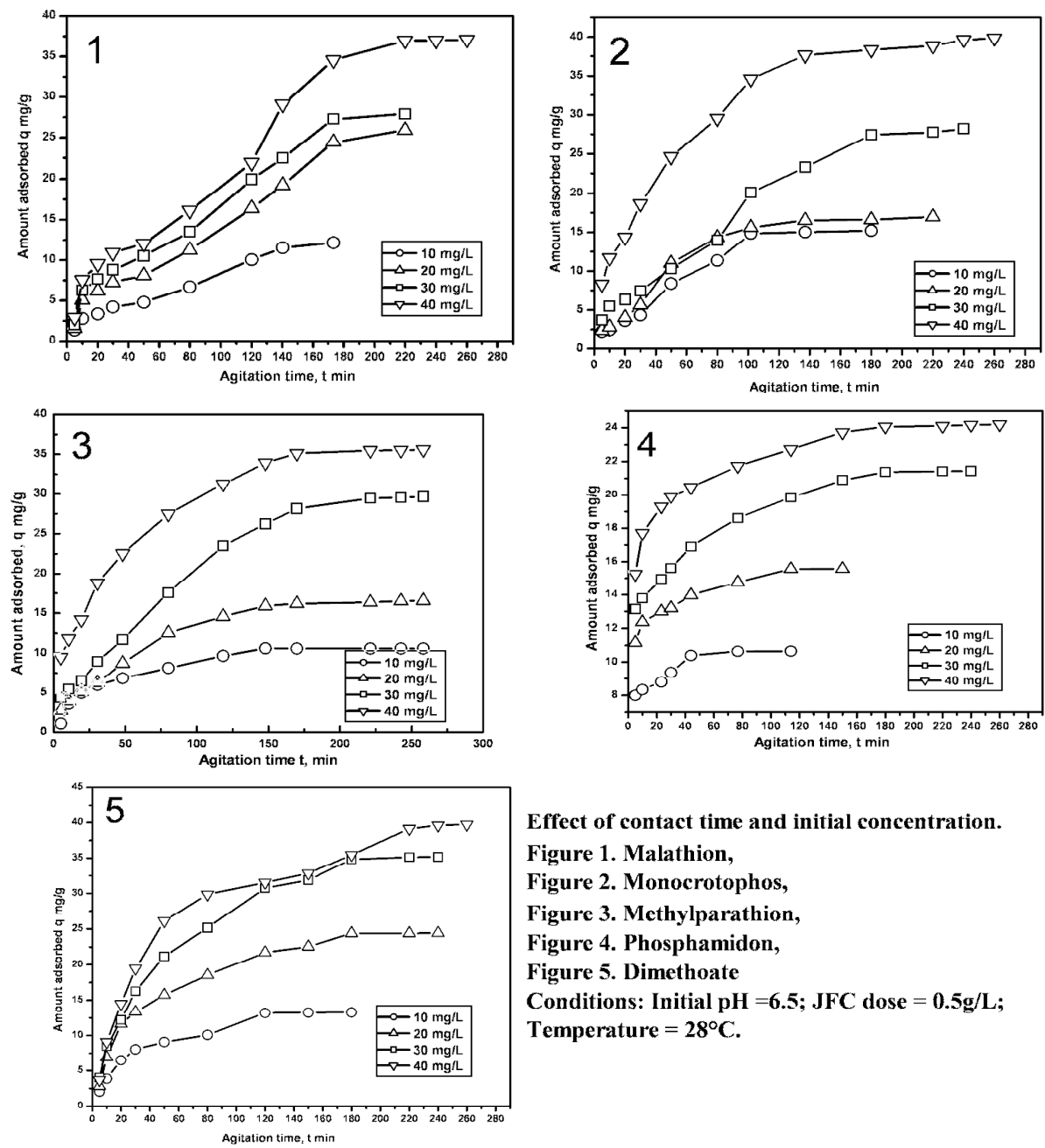

Effect of contact time and initial concentration.

Figure 1. Malathion,

Figure 2. Monocrotophos,

Figure 3. Methylparathion,

Figure 4. Phosphamidon,

Figure 5. Dimethoate

Conditions: Initial $\mathrm{pH}=6.5 ; \mathrm{JFC}$ dose $=0.5 \mathrm{~g} / \mathrm{L}$;

Temperature $=28^{\circ} \mathrm{C}$.

\section{Kinetic models}

For evaluating the adsorption kinetic of OPPs on JFC, the pseudo first order and the pseudo second order kinetic models were used. The Elovich model is used to explain adsorption behaviors that concur with the nature of chemical adsorption.

The pseudo first order and pseudo second order kinetic correlation coefficients, $r^{2}$ and SSE values are calculated from the plot of $\log \left(\mathrm{q}_{\mathrm{e}-\mathrm{q}} \mathrm{t}\right) v s$. $\mathrm{t}$ and $\mathrm{t} / \mathrm{q}_{\mathrm{t}} v s$. $\mathrm{t}$ (Figures 6-15) and the values are presented in the Table 2. According to Daneshvar et $a l^{36}$ the linear fit is better when SSE values are low. The results for the adsorption of malathion, monocrotophos and methylparathion with the low SSE value and $r^{2}>0.9$ of pseudo first order kinetic model is better for predicting the kinetic process in the experimental conditions than the pseudo second order kinetic model ${ }^{31,37}$. For phosphamidon and dimethoate studied as seen from Table 2, the lower values of SSE of pseudo second order model than that of pseudo first order model support the suitability of pseudo second order kinetic model to explain the adsorption onto JFC. Several researchers ${ }^{36,38}$ also reported the reasonable agreement of pseudo second order kinetic model. 

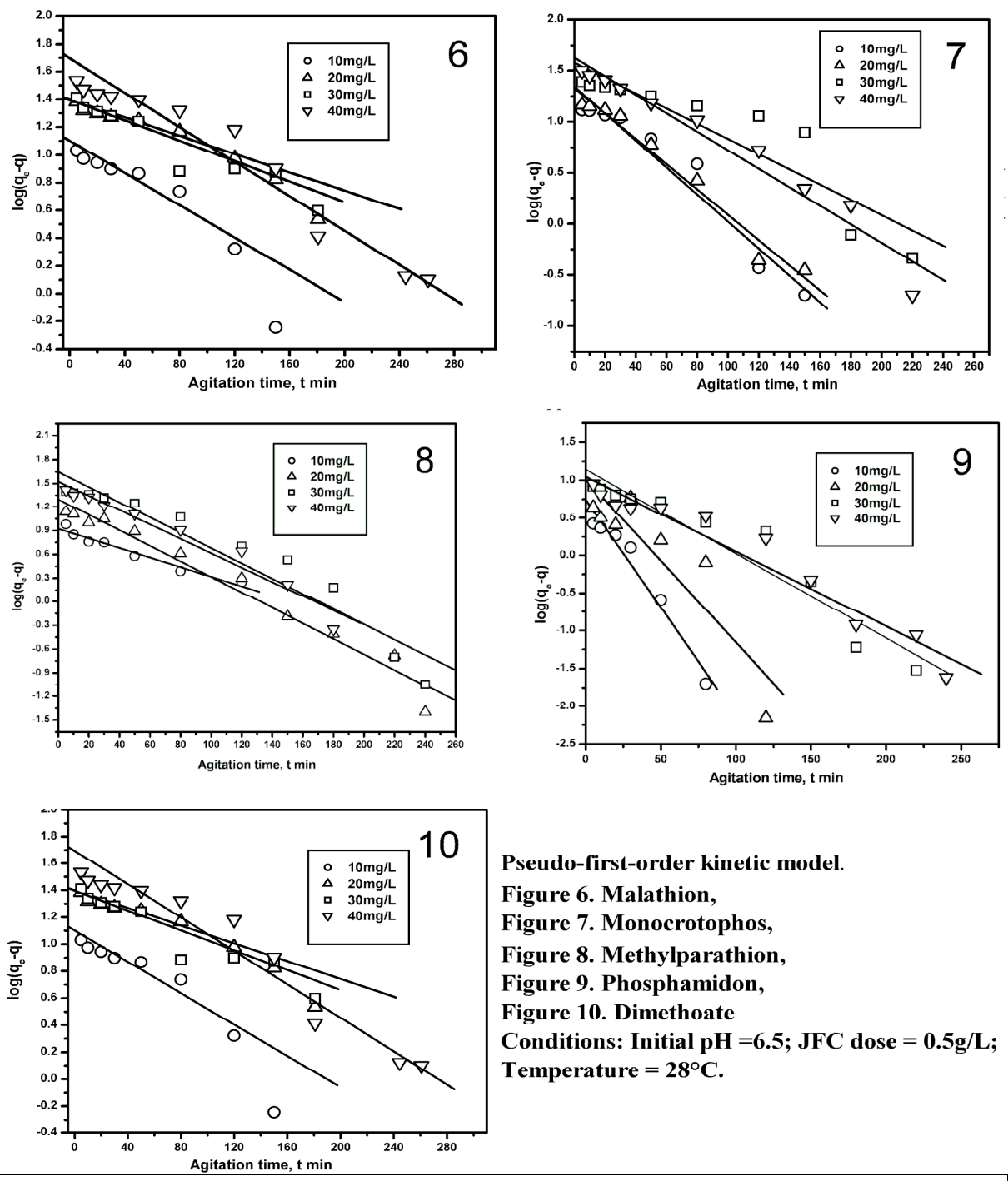

Pseudo-first-order kinetic model.

Figure 6. Malathion,

Figure 7. Monocrotophos,

Figure 8. Methylparathion,

Figure 9. Phosphamidon,

Figure 10. Dimethoate

Conditions: Initial $\mathrm{pH}=6.5 ; \mathrm{JFC}$ dose $=0.5 \mathrm{~g} / \mathrm{L}$;

Temperature $=28^{\circ} \mathrm{C}$.
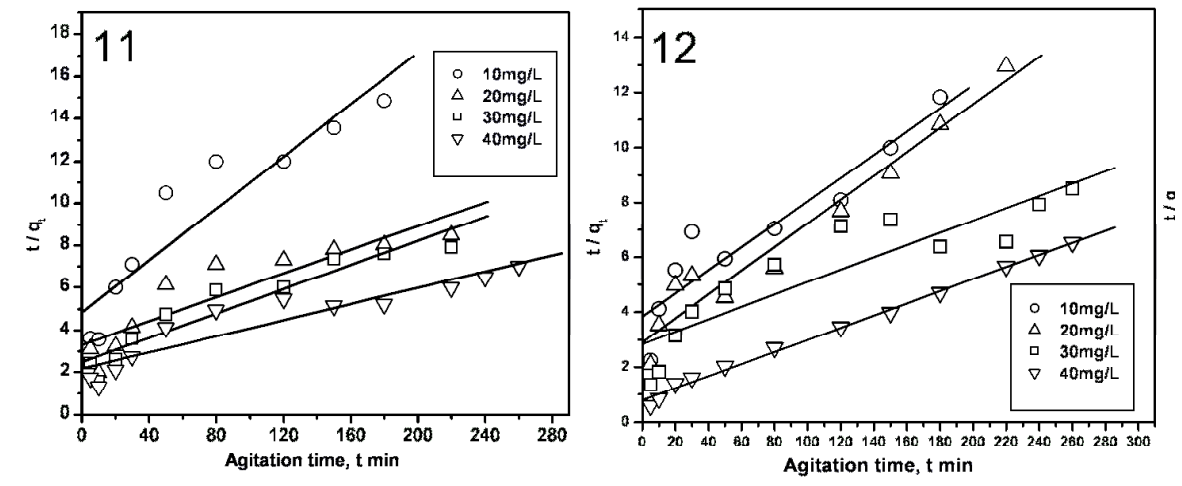

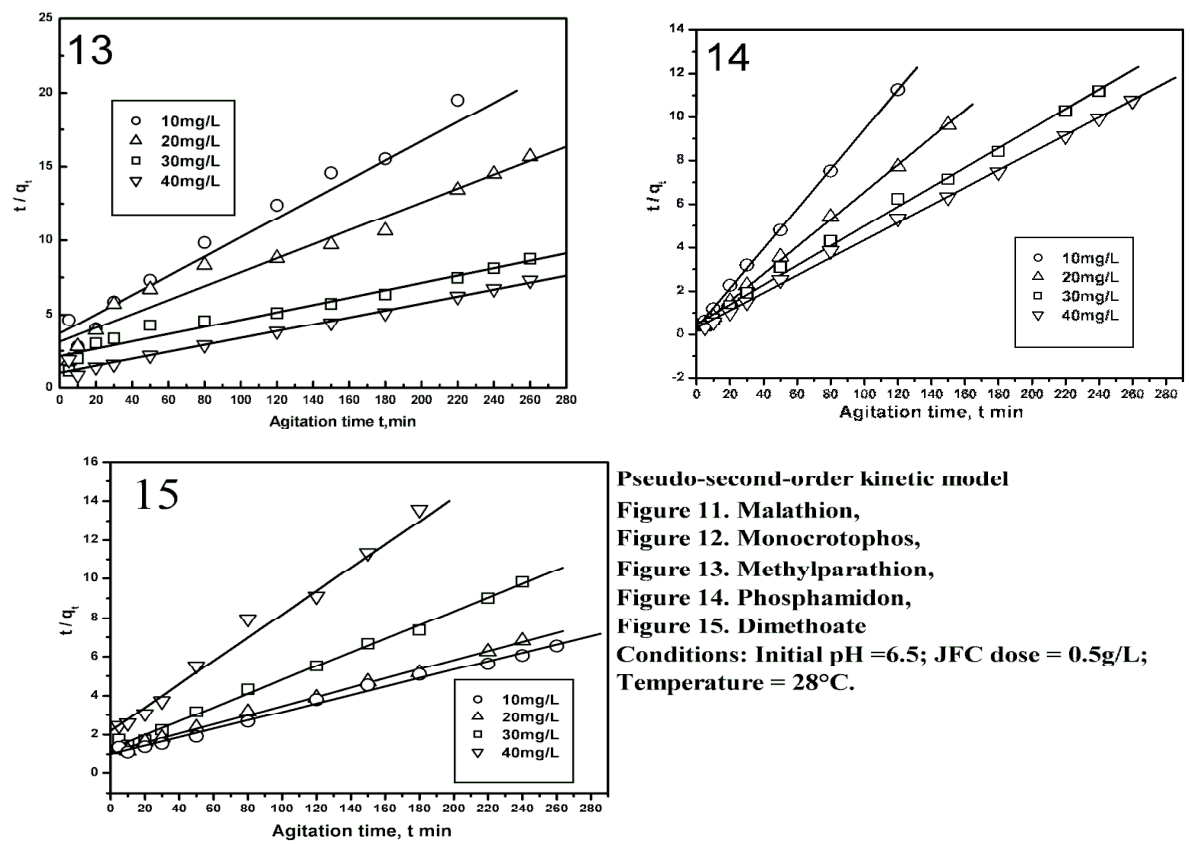

Table 2. Comparison of correlation coefficients and SSE values obtained from different kinetic models

\begin{tabular}{|c|c|c|c|c|c|c|c|}
\hline \multirow[t]{2}{*}{$\begin{array}{c}\text { Name of the } \\
\text { Pesticide }\end{array}$} & \multirow[t]{2}{*}{$\begin{array}{c}\text { Initial } \\
\text { Concentration, } \\
\mathrm{mg} / \mathrm{L} \\
\end{array}$} & \multicolumn{2}{|c|}{$\begin{array}{l}\text { Pseudo first } \\
\text { order kinetic } \\
\text { model }\end{array}$} & \multicolumn{2}{|c|}{$\begin{array}{l}\text { Pseudo second } \\
\text { order kinetic } \\
\text { model }\end{array}$} & \multicolumn{2}{|c|}{$\begin{array}{c}\text { Elovich } \\
\text { kinetic model }\end{array}$} \\
\hline & & $\mathrm{r}^{2}$ & SSE & $r^{2}$ & SSE & $\mathrm{r}^{2}$ & SSE \\
\hline \multirow{5}{*}{ Malathion } & 10 & 0.974 & 0.509 & 0.940 & 4.125 & 0.937 & 1.897 \\
\hline & 20 & 0.955 & 0.708 & 0.906 & 9.662 & 0.930 & 1.856 \\
\hline & 30 & 0.988 & 0.029 & 0.950 & 7.038 & 0.940 & 0.560 \\
\hline & 40 & 0.936 & 0.630 & 0.930 & 15.49 & 0.940 & 1.253 \\
\hline & 10 & 0.973 & 6.901 & 0.938 & 8.520 & 0.954 & 1.795 \\
\hline \multirow{4}{*}{ Monocrotophos } & 20 & 0.987 & 4.328 & 0.975 & 6.141 & 0.967 & 0.121 \\
\hline & 30 & 0.911 & 9.488 & 0.867 & 16.225 & 0.926 & 0.911 \\
\hline & 40 & 0.977 & 2.360 & 0.998 & 5.573 & 0.988 & 0.604 \\
\hline & 10 & 0.979 & 2.206 & 0.990 & 2.589 & 0.993 & 0.409 \\
\hline \multirow{4}{*}{ Methylparathion } & 20 & 0.984 & 3.358 & 0.980 & 4.646 & 0.980 & 0.285 \\
\hline & 30 & 0.959 & 3.312 & 0.977 & 9.792 & 0.961 & 0.431 \\
\hline & 40 & 0.969 & 3.334 & 0.993 & 9.093 & 0.981 & 0.640 \\
\hline & 10 & 0.981 & 5.083 & 0.9995 & 0.330 & 0.973 & 0.148 \\
\hline \multirow{3}{*}{ Phosphamidon } & 20 & 0.902 & 5.145 & 0.9994 & 0.376 & 0.992 & 0.053 \\
\hline & 30 & 0.959 & 7.487 & 0.998 & 0.849 & 0.975 & 0.069 \\
\hline & 40 & 0.973 & 13.001 & 0.990 & 0.628 & 0.982 & 0.063 \\
\hline & 10 & 0.952 & 3.971 & 0.994 & 6.638 & 0.993 & 1.274 \\
\hline \multirow[t]{3}{*}{ Dimethoate } & 20 & 0.950 & 5.467 & 0.998 & 2.804 & 0.998 & 0.265 \\
\hline & 30 & 0.940 & 17.119 & 0.999 & 5.284 & 0.994 & 0.127 \\
\hline & 40 & 0.918 & 6.211 & 0.996 & 4.717 & 0.996 & 0.348 \\
\hline
\end{tabular}


The SSE values calculated from the plot of $\mathrm{q}_{\mathrm{t}} v s . \ln \left(\mathrm{t}+\mathrm{t}_{\mathrm{o}}{ }_{\mathrm{o}}\right.$ (Figures 16-20) for the Elovich model are lies within $0.930-0.940,0.1212-1.795,0.2854-0.6399,0.0632-0.148$ and $0.127-$ 1.274 for the adsorption of malathion, monocrotophos, methylparathion, phosphamidon and dimethoate onto JFC. The correlation coefficient $r^{2}$, which are closer to one in the case of Elovich model. The agreement of the Elovich equation with experimental data may be explained as follows: The successful applications of the Elovich equation to heterogeneous catalyst surfaces helps to explain its success in predicting the sorption of all the pesticides studied on $\mathrm{JFC}^{39,40}$. The general explanations for this form of kinetic equation involves a variation of the energetic of chemisorption with the active sites are heterogeneous in JFC. This supports that the heterogeneous sorption mechanism likely to be responsible for the pesticides uptake. Elovich model basically supports chemisorption.
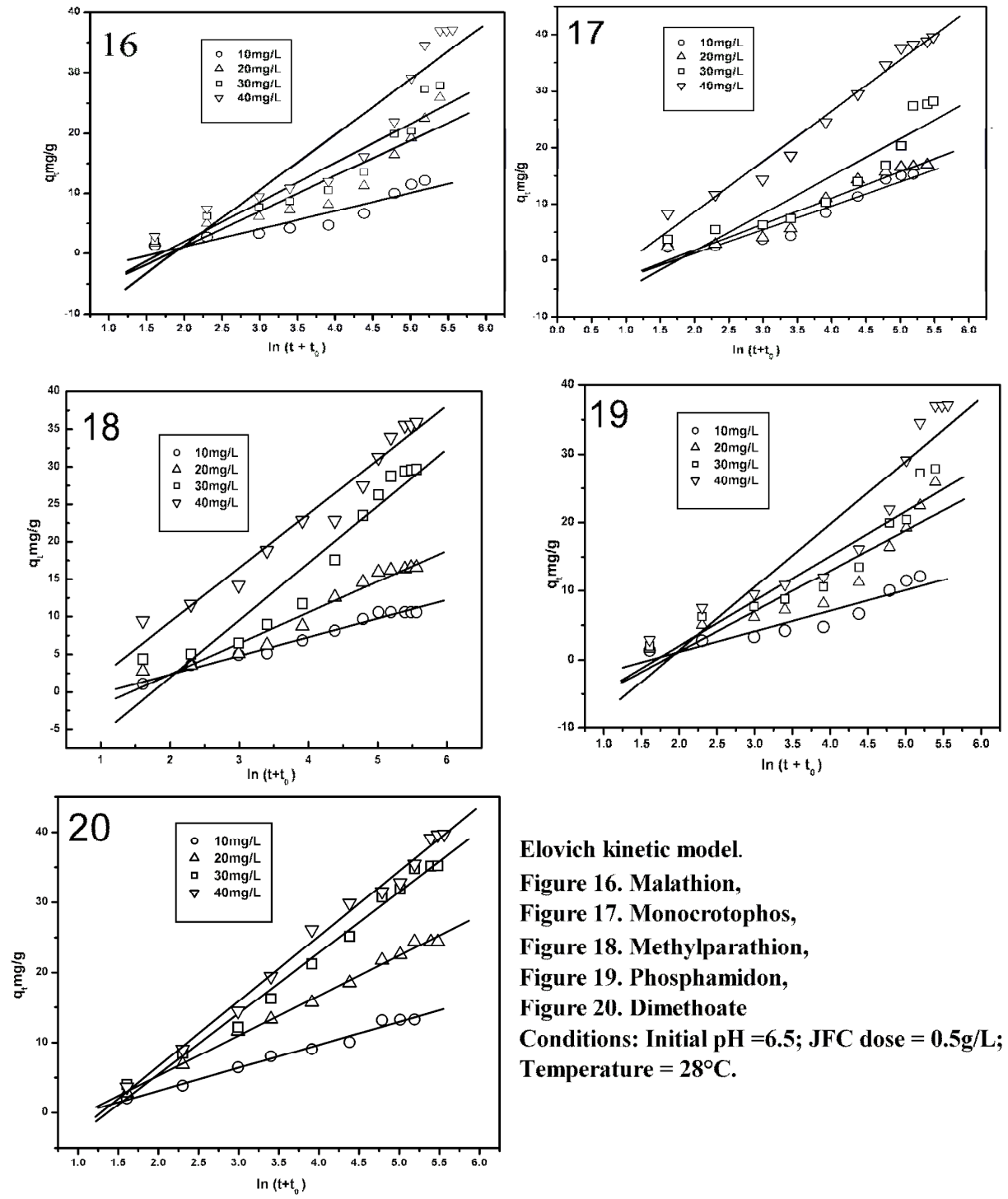

Elovich kinetic model.

Figure 16. Malathion,

Figure 17. Monocrotophos,

Figure 18. Methylparathion,

Figure 19. Phosphamidon,

Figure 20. Dimethoate

Conditions: Initial $\mathrm{pH}=6.5 ; \mathrm{JFC}$ dose $=0.5 \mathrm{~g} / \mathrm{L}$;

Temperature $=28^{\circ} \mathrm{C}$. 


\section{Conclusion}

- The adsorption of the pesticide was carried with "Waste" Jute Fiber Carbon as an adsorbent.

- The prepared activated carbon was analyzed by elemental and proximate method.

- From the effect of JFC dose study, adsorption increases with increase of JFC dose up to the equilibrium. malathion, monocrotophos and methylparathion adsorption onto JFC follows the first order kinetic model. The adsorption of phosphamidon and dimethoate onto JFC, which obey the pseudo second order kinetic model.

- The adsorption was supported by Elovich model.

Acknowledgment

The authors thank the Dongguk University-Seoul for their research funds to QSRC.

\section{References}

1. Memon G Z, Bhanger M I, Akthar M, Talpur F N and Memon J R, Chem Eng J., 2008, 138, 616-621.

2. Calderbank A, Rev Environ Contam Toxicol., 1989, 10, 29-192.

3. Gupta V K, Jain C K, Imran Ali, Chandra S and Agarval S, Water Res., 2002, 36, 2483-2490.

4. $\quad$ Saupe A, Chemosphere, 1999, 39(13), 2325-2346.

5. Yong Y, Wenyi T, Am J Biochem Biotech., 2005, 1, 173-175.

6. Souza D A and Lancas F M, J Environ Sci Health Part B., 2003, 38, 417-428.

7. Franco-garcia M L, Murat M, Percherancier J P and Pouyet B, Fresenius Environ Bull., 1996, 5, 563-568.

8. Fallmann H, Krutzler T, Bauer R, Malato S and Blanco J, Catal Today, 1999, 54(2,3), 309-319.

9. Thebault P, Cases J M and Fiessinger F, Water Res., 1981, 15, 183-189.

10. Varhney K G, Khan A A, Gupta U and Maheswari S M, Colloids Surf A: Physicochem Eng Aspects, 1996, 113, 19-23.

11. Mason Y Z, Choshen E and Rav-Acha C, Water Res., 1990, 24, 11-21.

12. Lambert S D and Graham N J D, Water Res., 1995, 29(10), 2421-2426.

13. Chatterjee S, Das S K, Chakravarty R, Chakrabarti A, Ghosh S and Guha A K, $J$ Hazard Mater., 2010, 174(1-3), 47-53.

14. Aksu Z and Kabasakal E, J Environ Sci Health Part B, 2007, 40(4), 545-570.

15. Ru J, Liu H J, Qu J H, Wang A M, Dai R H and Wang Z J, J Environ Sci Health Part B, 2007, 42(1), 53-61.

16. Qiu Y, Xiao X, Cheng H, Zhou Z and Sheng G D, Environ Sci Technol., 2009, 43, 4973-7978.

17. Cruz S R, Andrades M S, Camazano M S and Martin M J S, Environ Sci Technol., 2007, 41, 3613-3619.

18. Cruz M S R, Andrades M S, Parada A M and Martin M J S, J Agric Food Chem., 2008, 56, 7339-7346.

19. Islam M A, Sakkas V and Albanis T A, J Hazard Mater., 2009, 170(1), 230-238.

20. Akhtar M, Iqbal S, Bhanger M I, Zia-Ul-haq M and Moazzam M, Colloids Surf B: Biointerf., 2009, 69, 63-70.

21. Bakouri H E I, Usero J, Morillo J and Ouassini A, Bioresour Technol., 2009, 100(18), 4147-4155.

22. Li K, Zheng Z, Feng J, Zhang J, Luo X, Zhao G and. Huang X, J Hazard Mater., 2009, 166, 1180- 1185 . 
23. Akhtar M, Hasany S M, Bhanger M I and Iqbal S, Chemosphere, 2007, 66, 1829-1838.

24. Gupta V K, Jain C K, Ali I, Chanra S and Agarwal S, Water Res., 2002, 36(10), 2483- 2490.

25. Hameed B H, Salman J M and Ahmad A L, J Hazard Mater., 2009, 163, 121-126.

26. Bakouri H E I, Usero J, Morillo J, Rojas R and Ouassini A, Bioresour Technol., 2009, 100(1), 2676-2684.

27. Senthilkumaar S, Bharathi S, Nithyanandhi D and Subburaam C V, Bioresour Technol., 2000, 75(2), 163-165.

28. Senthilkumaar S, Kalaamani P, Porkodi K, Varadarajan P R and Subburaam C V, Bioresour Technol., 2006, 97, 1618-1625.

29. Senthilkumaar S, Kalaamani P and Subburaam C V, J Hazard Mater, 2006, 136, 800-808.

30. Senthilkumaar S, Kalaamani P, Porkodi K, Varadarajan P R and Subburaam C V, $J$ Colloid Interface Sci., 2005, 284(1), 78-82.

31. Lagergren S, Handlingar, 1898, 24, 1-39.

32. Ungarish M and Aharoni C, J Chem Soc - Faraday Trans., 1991, 77, 975- 985.

33. Low M J D, Chem Rev., 1960, 60, 267-312.

34. Juang R S and Chen M L, Ind Eng Chem Res., 1997, 36, 813 - 820.

35. Gupta V K and Ali I, Water Res., 2001, 35, 33-40.

36. Daneshvar N, Aber S, Khani A and Khataee A R, J Hazard Mater, 2007, 144, 47-51.

37. Ho Y S and Mc Kay G, Water Res., 1999, 33, 578-584.

38. Gupta V K, Ali I and Saini Suhas V K, J Colloid Interface Sci., 2006, 299, 556- 563.

39. Cheung C W, Porter J F and Mckay G, Water Res., 2001, 35(3), 605 - 612.

40. Ozacar M and Sengil A, Bioresour Technol., 2005, 96(7), 791-795. 


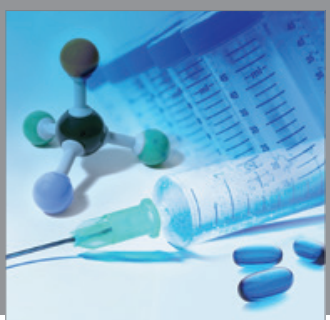

International Journal of

Medicinal Chemistry

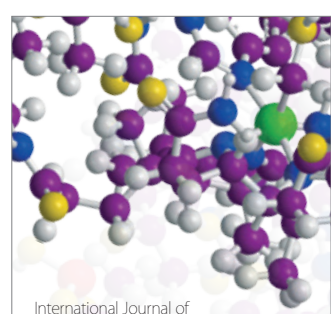

Carbohydrate Chemistry

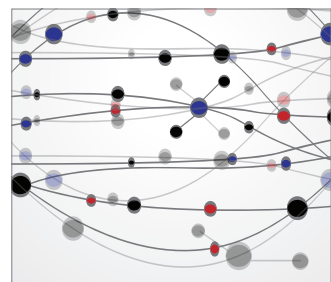

The Scientific World Journal
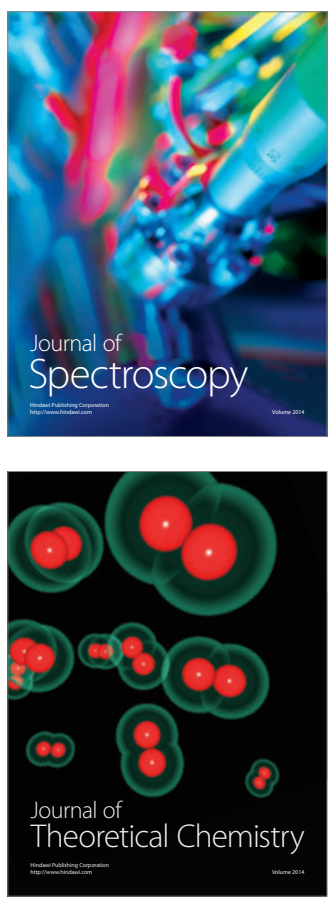
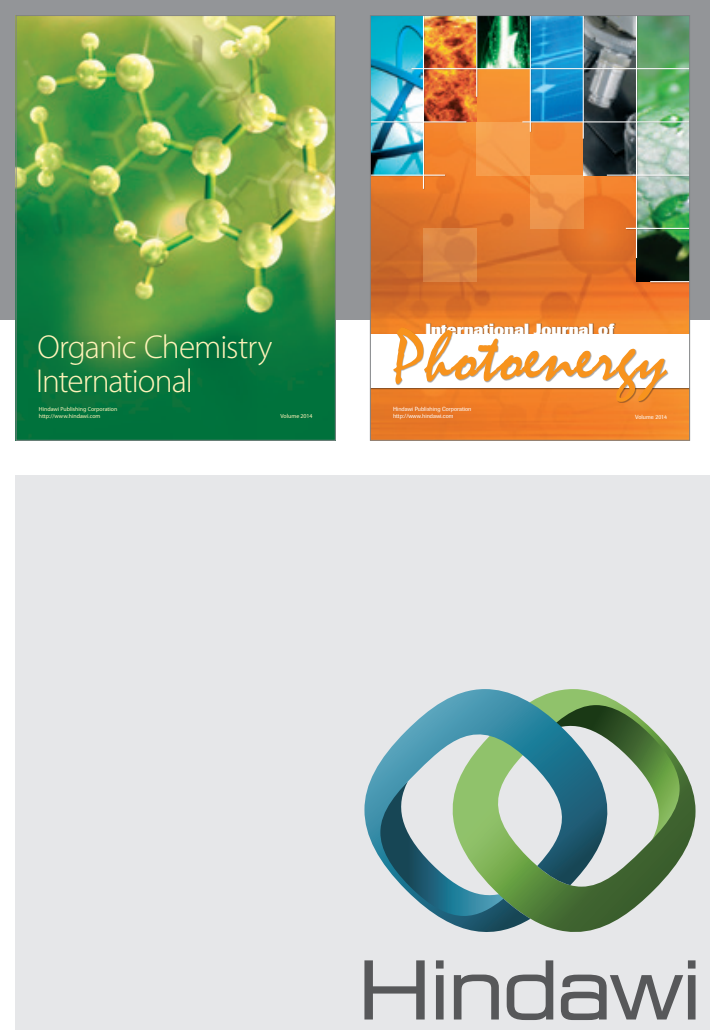

Submit your manuscripts at

http://www.hindawi.com
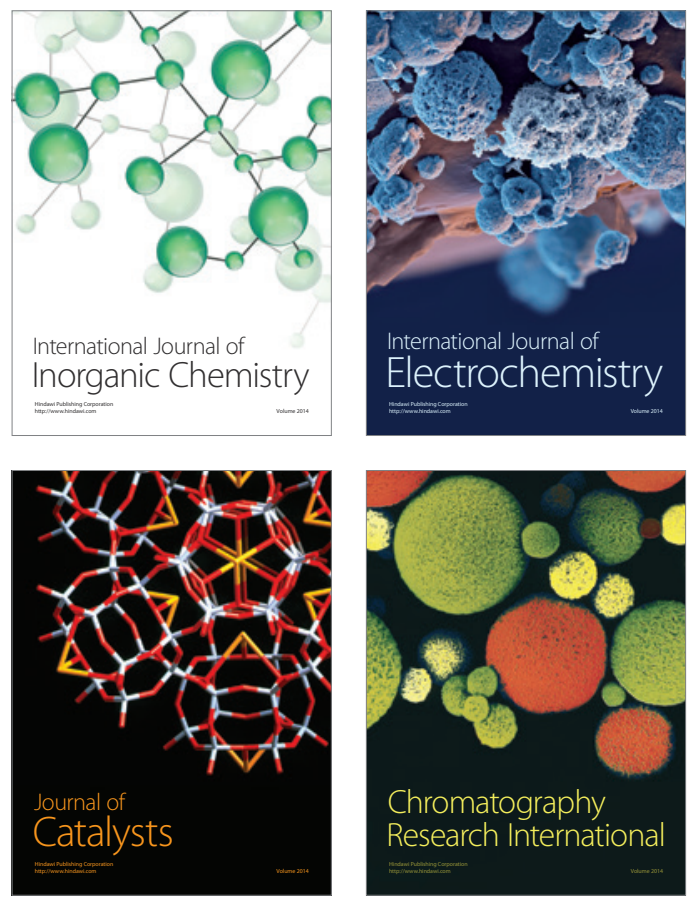
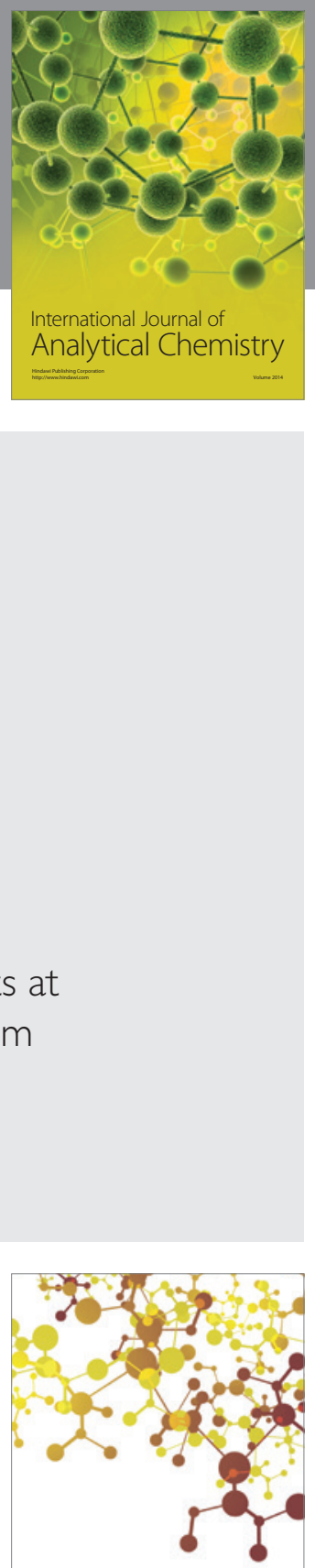

Journal of

Applied Chemistry
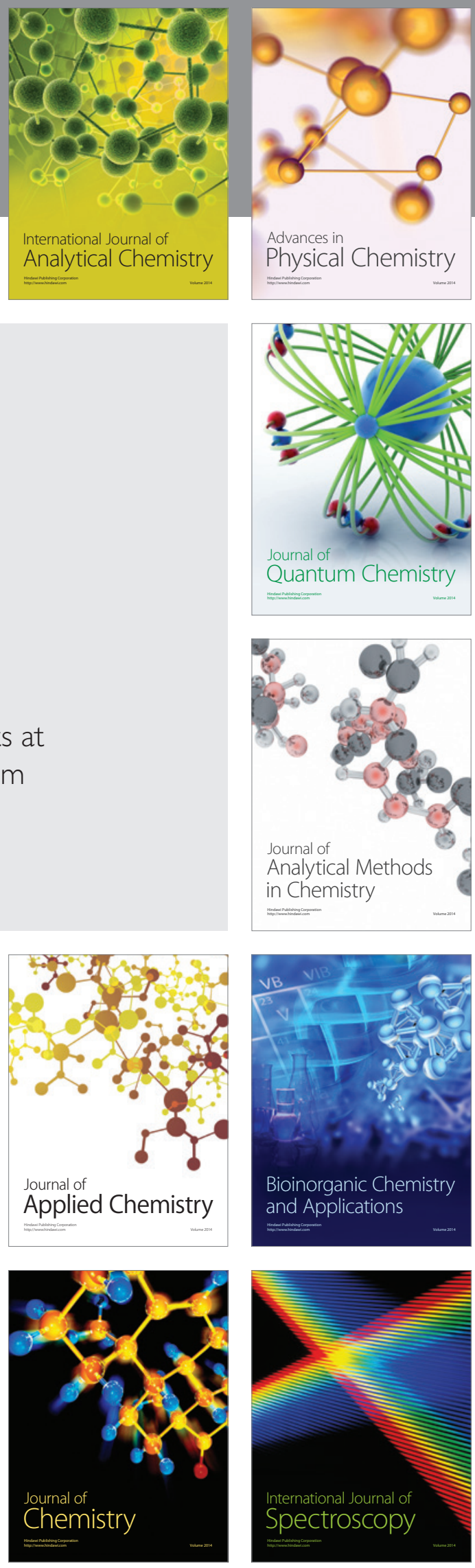